\title{
Enhanced rates of particulate organic matter remineralization by microzooplankton are diminished by added ballast minerals
}

\author{
F. A. C. Le Moigne ${ }^{1}$, M. Gallinari ${ }^{2}$, E. Laurenceau ${ }^{2,}$, and C. L. De La Rocha ${ }^{2}$ \\ ${ }^{1}$ Department of Ocean Biogeochemistry and Ecosystems, National Oceanography Centre, Southampton, UK \\ ${ }^{2}$ CNRS UMR6539, IUEM, Université de Bretagne Occidentale, Brest, France \\ * now at: CSIRO-UTAS Quantitative Marine Sciences Ph.D. Program, Institute for Marine and Antarctic Studies, Antarctic \\ Climate and Ecosystems Cooperative Research Centre, University of Tasmania, Commonwealth Scientific and Industrial \\ Research Organisation, Marine and Atmospheric Research, Hobart, Australia
}

Correspondence to: C. L. De La Rocha (christina.delarocha@univ-brest.fr)

Received: 29 January 2013 - Published in Biogeosciences Discuss.: 27 February 2013

Revised: 18 June 2013 - Accepted: 22 July 2013 - Published: 2 September 2013

\begin{abstract}
To examine the potentially competing influences of microzooplankton and calcite mineral ballast on organic matter remineralization, we incubated diatoms in darkness in rolling tanks with and without added calcite minerals (coccoliths) and microzooplankton (rotifers). Concentrations of particulate organic matter (POM in suspension or in aggregates), of dissolved organic matter (DOM), and of dissolved inorganic nutrients were monitored over 8 days. The presence of rotifers enhanced the remineralization of ammonium and phosphate, but not dissolved silicon, from the biogenic particulate matter, up to $40 \%$ of which became incorporated into aggregates early in the experiment. Added calcite resulted in rates of excretion of ammonium and phosphate by rotifers that were depressed by $67 \%$ and $36 \%$, respectively, demonstrating the potential for minerals to inhibit the destruction of POM by zooplankton in the water column. Lastly, the presence of the rotifers and added calcite minerals resulted in a more rapid initial rate of aggregation, although not a greater overall amount of aggregation during the experiment.
\end{abstract}

\section{Introduction}

The biological pump exports 5 to $10 \mathrm{Gt} C$ per year to the deep ocean as dissolved and particulate organic matter (Falkowski et al., 1998; Henson et al., 2011). Without such transfer of carbon to the deep, pre-industrial concentrations of atmospheric carbon dioxide $\left(\mathrm{CO}_{2}\right)$ would have been almost twice as high as they are (Broecker and Peng, 1982; Parekh et al., 2006) and a greater portion of annual anthropogenic $\mathrm{CO}_{2}$ emissions would remain in the atmosphere, accelerating the growth of atmospheric $\mathrm{CO}_{2}$ (Le Quéré et al., 2010). The processes controlling the efficiency of particulate organic matter (POM) export by the biological pump are thus critical with respect to global climate change.

A long-known correlation between fluxes of minerals (biogenic calcite, biogenic opal, and lithogenic material like clays) and of particulate organic carbon (POC) sinking into sediment traps in the deep sea (Deuser et al., 1981) has been recently revisited as the "ballast hypothesis" that suggests sinking fluxes of minerals control the export of POC to the deep sea (Armstrong et al., 2002; François et al., 2002; Klaas and Archer, 2002). Minerals could provide organic matter with protection from remineralization and/or excess density that increases sinking velocities, increasing POC export efficiency (Armstrong et al., 2002; François et al., 2002; Klaas and Archer, 2002; Passow et al., 2003; Ploug et al., 2008; Engel et al., 2009b; Fischer and Karakaş, 2009; Lee et al., 2009; Sanders et al., 2010).

Subsequent research has shown that while addition of mineral ballast to aggregates can increase their sinking velocity (De La Rocha and Passow, 2007; Ploug et al., 2008; Thomalla et al., 2008; Engel et al., 2009b; Lee et al., 2009; Iversen and Ploug, 2010; Sanders et al., 2010; Riley et al., 2012), little evidence has emerged for minerals protecting organic matter in the water column from remineralization or solubilization (Ingalls et al., 2006; Engel et al., 2009a; 
Iversen and Ploug, 2010). In the only reported case, aggregates of a calcifying strain of Emiliania huxleyi degraded more slowly relative to those of a non-calcifying strain (Engel et al., 2009a), but the underlying mechanisms, undetermined, could have been exclusion of bacteria or ectoenzymes from the coccolith-laden aggregates, or differences in the physiological condition or composition of the two strains of E. huxleyi. Conversely, experiments that directly investigated carbon-specific respiration rates of aggregates (Iversen and Ploug, 2010) have not found differences related to the presence of ballast minerals. No study has yet examined whether mineral ballast reduces the rate of remineralization driven by grazing by marine zooplankton, especially with respect to aggregates, although suspended particles of clay and calcite are known to interfere with feeding by Daphnia sp. in freshwater systems (Vanderploeg et al., 1987; Kirk, 1991).

To address whether incorporation of calcite into aggregates affects rates of solubilization and remineralization mediated by bacteria and/or microzooplankton, we allowed diatoms to aggregate in the presence and absence of calcite minerals and microzooplankton (rotifers) and then monitored nutrients, POM, and DOM in the tanks over 8 days.

\section{Materials and methods}

\subsection{Experimental set-up}

Experiments were carried out in cylindrical tanks kept in rotation on motorized tables to allow particles to sink freely throughout the experiment (Shanks and Trent, 1980; Passow and De La Rocha, 2006; De La Rocha et al., 2008). Twelve $4.5 \mathrm{~L}$ tanks were set up, covering three replicates of four different treatments: phytoplankton only $(\mathrm{P})$, phytoplankton + minerals $\quad(\mathrm{PM}), \quad$ phytoplankton + microzooplankton (PZ), and phytoplankton + microzooplankton + minerals (PMZ). Tanks were kept in darkness at $15^{\circ} \mathrm{C}$ in rotation at $1.5-3$ rpms.

All tanks contained a mixture of seawater filtered through a $0.6 \mu \mathrm{m}$ polycarbonate filter to remove phytoplankton and microzooplankton but not bacteria and an equal volume mixture of two diatom cultures, Skeletonema marinoï and Chaetoceros gracilis, grown in a modified $\mathrm{f} / 2$ medium $\left(\mathrm{Si}(\mathrm{OH})_{4}=50 \mu \mathrm{M} ; \mathrm{PO}_{4}=4 \mu \mathrm{M} ; \mathrm{NO}_{3}=64 \mu \mathrm{M}\right.$, and vitamins and trace elements in $\mathrm{f} / 2$ quantities). Calcite was added to tanks 3, 7, and 11. Microzooplankton (the marine rotifer Brachionus sp.) were added to tanks 2, 6, and 10. Microzooplankton and minerals were added to tanks 4,8 , and 12. Approximately 6200 rotifers per liter were added to all rotifer containing tanks except T10, which received only 4400 rotifers per liter. These values fall well within the typical range of rotifer concentrations in coastal waters of up to 8000 individuals per mL (Castilho and Arcifa, 2000).

The calcite was prepared from Cretaceous (Maastrichtian) chalk from the cliffs of Rügen, Germany. The chalk was disaggregated, gently ground, soaked overnight in bleach, and then rinsed with deionized distilled water (Milli-Q). The calcite was then suspended in artificial sea water $\left(1.68 \mathrm{~g} \mathrm{~L}^{-1} \mathrm{NaHCO}_{3}, 71.25 \mathrm{gL}^{-1} \mathrm{MgSO}_{4}\right.$ and $321.25 \mathrm{~g} \mathrm{~L}^{-1} \mathrm{NaCl}$ ) and those particles remaining in suspension after several minutes were used in the experiment. A similar suspension used by De La Rocha et al. (2008) consisted of coccoliths and smaller calcium carbonate debris.

The final experimental concentration of calcite was $1.3 \mathrm{mg} \mathrm{L}^{-1}$. This is slightly, but not unreasonably, higher than concentrations of caclium carbonate observed during coccolithophore blooms in the North Atlantic, which fall into the range of 0.4 to $0.8 \mathrm{mg} \mathrm{CaCO}_{3} \mathrm{~L}^{-1}$ (Harlay et al., 2011). At the same time, the PIC: POC ratio at the beginning of the experiment (around 0.1 in units of $\mathrm{gC}: \mathrm{gC}$ ) is slightly low compared to coccolithophore blooms, which tend to have values around 0.3 to $0.7 \mathrm{~g} \mathrm{Cg}^{-1} \mathrm{C}$.

The experiment lasted 8 days, with tanks sampled on days $0,2,4$, and 8. Aggregates were gently removed with a $10 \mathrm{~mL}$ disposable pipette whose tip had been cut off. The aggregates were combined and subsampled for various parameters and the now aggregate-free "background" water in the tanks was sampled for the material remaining in suspension.

\subsection{Bacteria counts and ectoenzyme activity}

Background water samples were fixed with $2 \%$ formalin, flash frozen in liquid nitrogen, then stored at $-80^{\circ} \mathrm{C}$ until preparation for counting. Tween 80 was added to detach bacteria from POM (Yoon and Rosson, 1990). Samples were sonicated in an ice bath, stained with SYBR gold (Invitrogen), and then mounted on black polycarbonate filters $(0.22 \mu \mathrm{m})$ using a $1: 1$ mixture of phosphate buffer solution and glycerol and $0.01 \%$ p-phenylenediamine as a preservative during storage at $-20^{\circ} \mathrm{C}$ until further counting. More than 200 bacteria were typically counted per sample using an Olympus epifluorescence microscope.

Aminopeptidase activity was measured using Lleucinemethyl coumarinyl amide (Leu-MCA) in methyl Cellosolve as substrate analogue (Hoppe et al., 1988). Samples were incubated in duplicate across a range of leucine concentrations and with sterile-filtered and boiled seawater controls (Hoppe et al., 1988). Fluorescence was measured in a FP-1520 spectrofluorometer (JASCO) at a $364 \mathrm{~nm}$ excitation wavelength and a $445 \mathrm{~nm}$ emission wavelength. Final results are expressed in terms of maximal velocities $\left(V_{\max }\right)$ from fitting a Michaelis-Menten curve through the resulting data using the curve fitting routine in SigmaPlot.

\subsection{Nutrients and dissolved organic matter}

Silicate, nitrate + nitrite, and phosphate were measured using a Bran + Luebbe AAIII auto-analyser as described by Aminot and Kerouel (2007). Ammonium was measured manually by 
spectrophotometry (Shimatzu UV 1700) as described by Koroleff (1969).

Samples for dissolved organic carbon (DOC), nitrogen (DON), and phosphorus (DOP) were filtered through precombusted $\left(450^{\circ} \mathrm{C}, 4 \mathrm{~h}\right)$ Whatman $\mathrm{GF} / \mathrm{F}$ filters into acid cleaned HDPE bottles and stored frozen $\left(-20^{\circ} \mathrm{C}\right)$ until analysis. DOC and total dissolved nitrogen (TDN) were measured using a Shimadzu TOC VCSH Total Organic Carbon Analyzer with the TNM-1 Total Nitrogen detector, according to methods of Pan et al. (2005). DON concentrations were calculated as the difference between TDN and dissolved inorganic nitrogen (the sum of nitrate, nitrite, and ammonium). For DOP, filtered samples were frozen at $-20^{\circ} \mathrm{C}$ in precombusted borosilicate vials until analysis via a segmented flow automated method with on-line photo- oxidation (Aminot and Kerouel, 2001).

\subsection{Particulate matter}

Particulate organic carbon (POC) and nitrogen (PON) were filtered onto pre-combusted $\left(450^{\circ} \mathrm{C}, 4 \mathrm{~h}\right)$, pre-weighed Whatman GF/F filters, rinsed with MilliQ water, and dried at $60^{\circ} \mathrm{C}$. Filters were fumed with $\mathrm{HCl}$ to remove inorganic carbon before measurement with a Flash 1112 series elemental NC analyser ThermoQuest as described in Lorrain et al. (2003). Total particulate phosphorus (TPP) was filtered onto pre-combusted $\left(450^{\circ} \mathrm{C}, 4 \mathrm{~h}\right)$ Whatman $\mathrm{GF} / \mathrm{F}$ filters and rinsed with filtered seawater. Filters were dried at $60^{\circ} \mathrm{C}$ then frozen. Defrosted filters were rinsed with $0.17 \mathrm{M} \mathrm{Na}_{2} \mathrm{SO}_{4}$ and placed in precombusted borosilicate vials with $17 \mathrm{mM} \mathrm{MnSO}_{4}$, covered with aluminum foil, dried at $95^{\circ} \mathrm{C}$, and stored in a desiccator. Vials were combusted at $450{ }^{\circ} \mathrm{C}$ for $2 \mathrm{~h}$ and then digested with $0.2 \mathrm{NHCl}$ at $80^{\circ} \mathrm{C}$ for $30 \mathrm{~min}$ before phosphate measurement via the standard molybdate method (Aminot and Kerouel, 2007).

Particulate inorganic carbon (PIC) was filtered onto $0.4 \mu \mathrm{m}$ Millipore polycarbonate filters, rinsed with MilliQ water, dried, and then digested in $0.4 \mathrm{M}$ nitric acid. $\mathrm{Ca}$ and $\mathrm{Na}$ were determined using a PerkinElmer Optima 4300 DV inductively coupled plasma optical emission spectrometer (ICPOES) as described in Poulton et al. (2006). PIC was calculated assuming that all PIC was $\mathrm{CaCO}_{3}$. Low Na concentrations indicated lack of sea salt $\mathrm{Ca}$ on the filters. Biogenic silica $\left(\mathrm{bSiO}_{2}\right)$ was filtered onto $0.4 \mu \mathrm{m}$ polycarbonate filters (Millipore) and dried at $60^{\circ} \mathrm{C}$ then dissolved in $4 \mathrm{~mL}$ of $0.2 \mathrm{M} \mathrm{NaOH}$ at $100^{\circ} \mathrm{C}$ for $60 \mathrm{~min}$ (Ragueneau et al., 2005), neutralized with $1 \mathrm{M} \mathrm{HCl}$, and determined colorimetrically as dissolved silicon.

\subsection{Photosynthetic parameters}

Measurements of the quantum yield of photosynthesis $F_{\mathrm{v}} / F_{\mathrm{m}}$, were made for suspended cells and cells in aggregates via pulse amplitude modulated (PAM) fluorometry (AquaPen-C AP-C 100). Samples were dark adapted for
10-15 min before measurement of $F_{\mathrm{m}}$ (maximum chlorophyll fluorescence) and $F_{\mathrm{t}}$ (instantaneous chlorophyll fluorescence, which, in dark adapted cells, is equivalent to $F_{\mathrm{o}}$, emission by excited chlorophyll a in photosystem II antennae). $F_{\mathrm{v}}$, the maximum capacity for photosynthetic quenching, was calculated as the difference between $F_{\mathrm{m}}$ and $F_{\mathrm{o}}$ (i.e. $F_{\mathrm{v}}=F_{\mathrm{m}}-F_{\mathrm{o}}$ ).

\section{Results}

\subsection{Formation of aggregates}

Aggregates $>1 \mathrm{~mm}$ formed overnight in all but the $\mathrm{P}$ treatment (Figs. 1-4). By the day 2 sampling day, a higher proportion of $\mathrm{POM}$ and $\mathrm{bSiO}_{2}$ had been incorporated into aggregates in the PM and PZM treatments than in the PZ treatment (Fig. 5). By day 4, the $\mathrm{P}$ tanks also contained aggregates $>1 \mathrm{~mm}$ (Figs. 1-4), although they represented a smaller fraction of the total POM than in the PZ, PM, and PZM treatments (Fig. 5). These differences between the treatments disappeared by the end of the experiment.

The different initial rates of aggregation were likely related to the presence of zooplankton and added minerals. There were no differences in phytoplankton physiology (exemplified by $F_{\mathrm{v}} / F_{\mathrm{m}}$; Fig. 6) or in concentrations of transparent exopolymer particles (TEP) (E. Laurenceau, personal communication, 2012) or bacteria (Fig. 7) because all experimental tanks were filled at the same time from the same large reservoir of phytoplankton and seawater. Further examination of the aggregation will be given in another manuscript.

\subsection{Decline in the condition of the phytoplankton}

The phytoplankton were initially relatively healthy, showing quantum efficiency of photosystem II $\left(F_{\mathrm{v}} / F_{\mathrm{m}}\right)$ of 0.6 on day 0 (Parkhill et al., 2001) (Fig. 6), but $F_{\mathrm{v}} / F_{\mathrm{m}}$ declined dramatically during the incubation, not due to any lack of nutrients (Fig. 8), but to the dark conditions of the incubation. By day $2, F_{\mathrm{v}} / F_{\mathrm{m}}$ had dropped to $\sim 0.4$ in all treatments (Fig. 6), indicating cells under stress. By day $4, F_{\mathrm{v}} / F_{\mathrm{m}}$ had dropped below 0.1 for cells in aggregates in the P, PM, and PZM tanks, indicating cells in extreme stress while $F_{\mathrm{v}} / F_{\mathrm{m}}$ remained $\sim 0.3$ for non-aggregated cells in all tanks and for cells in aggregates in the $\mathrm{PZ}$ tank.

\subsection{Bacterial abundance and aminopeptidase activity}

Bacteria occurred in both the water in the tanks (Fig. 7), at typical concentrations of $1.5 \times 10^{6}$ to $3.5 \times 10^{6}$ cells per $\mathrm{mL}$, and within the aggregates (their abundance within the aggregates was not ascertained). The number of bacteria suspended in the water in the tanks did not vary systematically between treatments or over time, except within the range of error of the counts. 

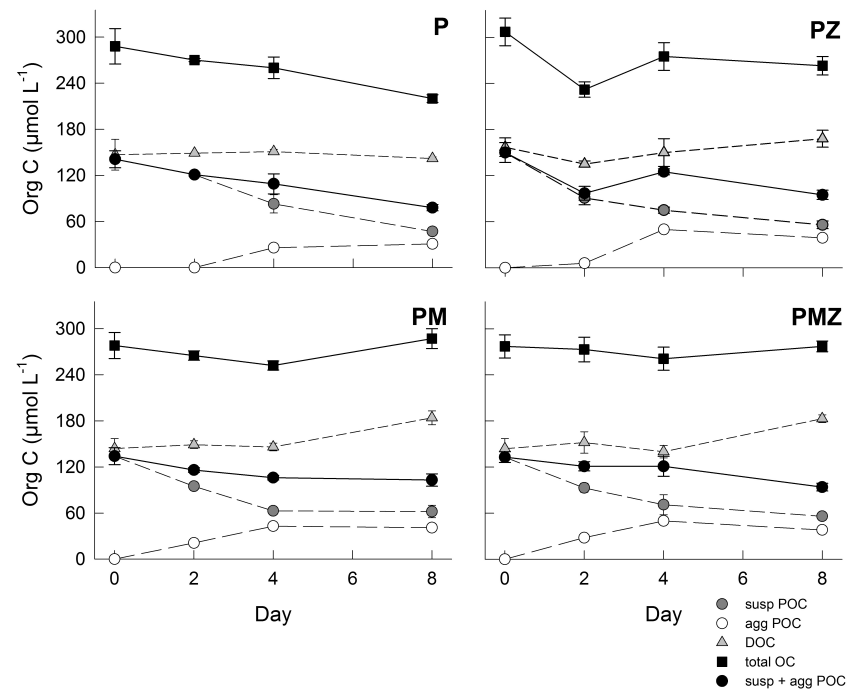

Fig. 1. Concentrations of DOC, total POC, suspended POC, and $\mathrm{POC}$ in aggregates in the 4 treatments during the experiment.
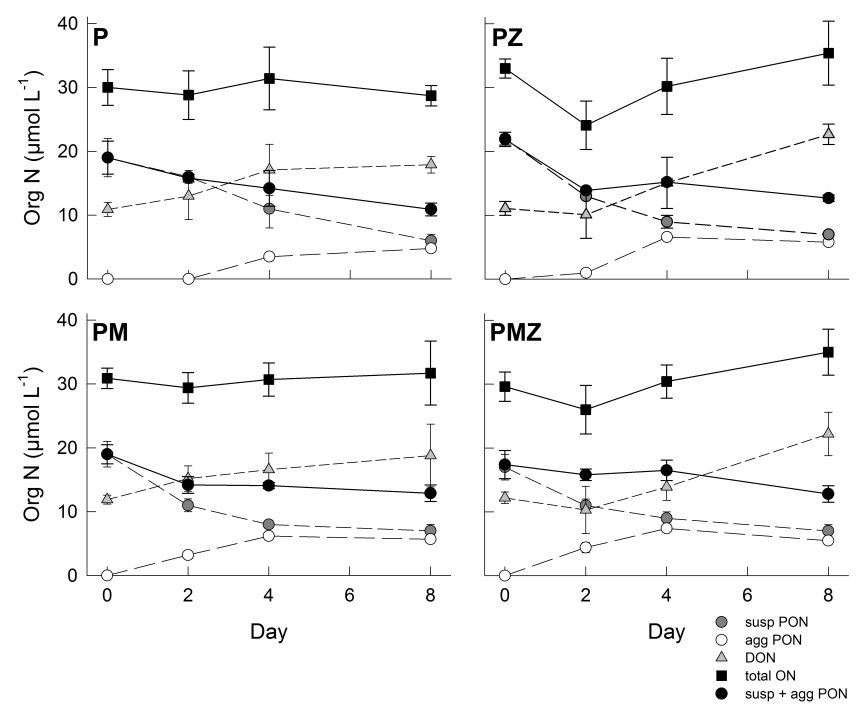

Fig. 2. Concentrations of DON, total PON, suspended PON, and $\mathrm{PON}$ in aggregates in the 4 treatments during the experiment.

Aminopeptidase activities show that the bacteria were active in the tanks (Fig. 9). On day 0, the pattern for aminopeptidase activity was the same in all of the treatments, with a maximum velocity $\left(V_{\max }\right)$ for leucine hydrolysis of $227 \pm 10 \mathrm{~h}^{-1}$ and a half saturation constant $\left(K_{\mathrm{s}}\right)$ of $192 \pm 18 \mu \mathrm{M}\left(r^{2}=0.99\right)$. By day $8, V_{\max }$ and $K_{\mathrm{S}}$ had decreased in all tanks, although the decrease in $V_{\max }$ was smaller in the two mineral containing treatments, which also experienced the greater decrease in $K_{\mathrm{S}}$ (Fig. 9). The divergence in $V_{\max }$ and $K_{\mathrm{s}}$ values among the different treatments may reflect shifts in the bacterial population in each tank or
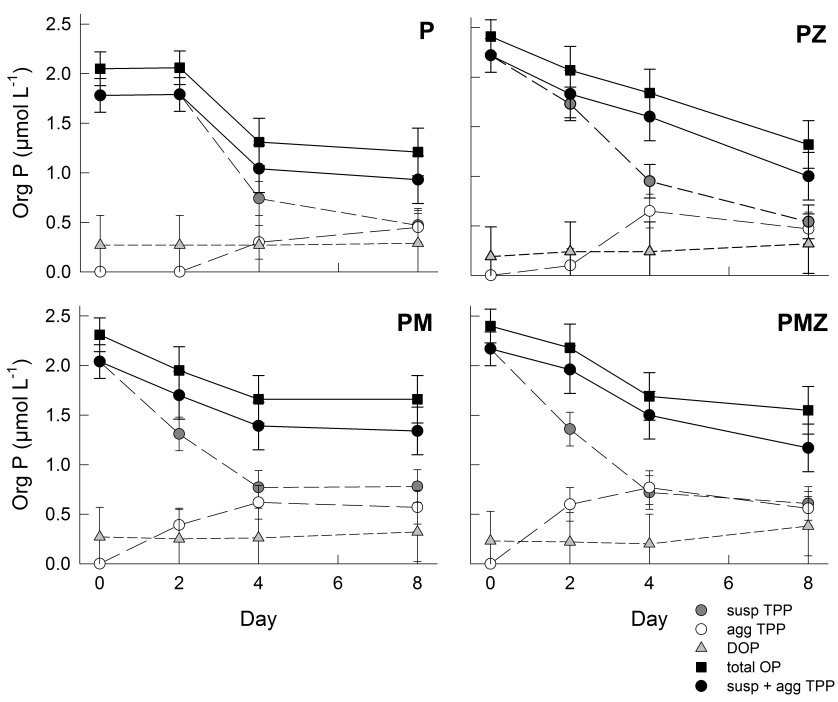

Fig. 3. Concentrations of DOP, total TPP, suspended TPP, and TPP in aggregates in the 4 treatments during the experiment.
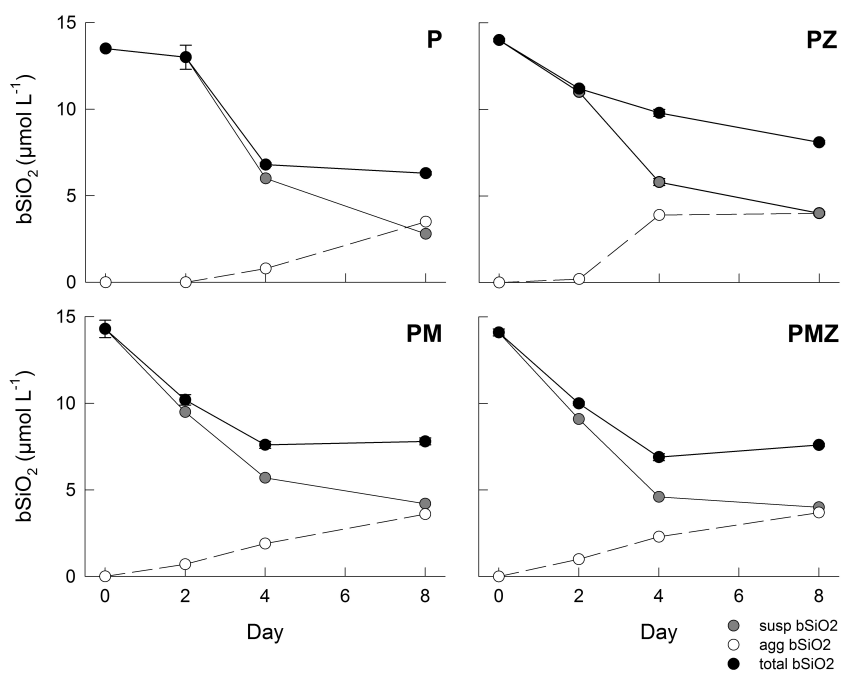

Fig. 4. Concentrations of total $\mathrm{bSiO}_{2}$, suspended $\mathrm{bSiO}_{2}$ and $\mathrm{bSiO}_{2}$ in aggregates in the 4 treatments during the experiment.

to the response of the bacterial community to changes in the composition of DOM in the different treatments.

\subsection{Dissolved and particulate matter}

Concentrations of suspended particulate matter decreased during the experiment (Figs. 1-4), with $30-40 \%$ of the initial POC, PON, TPP, and $\mathrm{bSiO}_{2}$ remaining in suspension at the end of the experiment. Overall, $\sim 44 \%$ of the loss of suspended POC and PON and $\sim 36 \%$ of the loss of suspended $\mathrm{bSiO}_{2}$ and TPP could be attributed to incorporation into aggregates. The rest of the loss had to be due to oxidation (remineralization) and solubilization (DOM production). 
Concentrations of most nutrients increased during the experiment, indicating net remineralization of organic matter and silica. DSi, indicative of biogenic silica dissolution, increased by $\sim 4 \mu \mathrm{M}$ to an average end concentration of $22.0 \pm 0.4 \mu \mathrm{M}$ (Fig. 8), effectively equalling the total recorded loss of $6 \mu \mathrm{mol} \mathrm{L}-1 \mathrm{bSiO}_{2}$ (Fig. 4). Nitrite (indicative of nitrification) increased on average from $0.27 \pm 0.02 \mu \mathrm{M}$ at day 0 to $0.70 \pm 0.08 \mu \mathrm{M}$ on day 8 (Fig. 8). Ammonium (Fig. 8) roughly doubled in the P and PM tanks and increased five- to tenfold in the PZ and PZM tanks. Phosphate (Fig. 8 ) increased by $\sim 0.5 \mu \mathrm{M}$ in the $\mathrm{P}$ and PM treatments and by $\sim 0.9 \mu \mathrm{M}$ in the $\mathrm{PZ}$ and PZM treatments.

Nitrate was the only nutrient not to show a general increase during the experiment, remaining relatively close to $23 \mu \mathrm{M}$ in the $\mathrm{P}$ and $\mathrm{PM}$ tanks and not rising above $27 \mu \mathrm{M}$, even in the zooplankton-containing tanks (Fig. 8). This is unsurprising as during the relatively short duration of the experiment (8 days), significant quantities of nitrate would not be expected to be formed from nitrite and ammonium via nitrification (Von Brand et al., 1942).

Between the beginning and end of the experiment, concentrations of dissolved organic nitrogen (DON) generally increased and those of dissolved organic phosphorus (DOP) and dissolved organic carbon (DOC) did not change very much (aside from the exceptionally elevated DOC values on day 8 in the PM and PZM tanks which may reflect contamination). The pools of DOM represent the accumulation of inputs through solubilization minus outputs through oxidation, suggesting that the microzooplankton drove enhanced net production of DON and DOP between day 0 and 8 (although not between day 0 and 4) (Figs. 2-3). Added minerals had no clear impact on DON and DOP concentrations. If the two elevated end values of DOC in the two mineralcontaining treatments are to be believed, then between day 0 and day 8 , the presence of added calcite resulted in an enhanced net production of DOC (Fig. 5).

\section{Discussion}

The efficiency of POM export from the upper ocean is determined by the sinking rate of this material, some of which forms large, rapidly sinking aggregates, and its oxidation rate back to inorganic nutrients and $\mathrm{CO}_{2}$. The controls over the rate of destruction of sinking particles (aggregates), both in terms of conversion to non-sinking organic matter, like small particles and DOM, and of remineralization to inorganic nutrients and $\mathrm{CO}_{2}$, lie largely with zooplankton of various size classes and bacteria, with different contributions from each at different times, places, and depths (e.g. Iversen et al., 2010). Unfortunately, our understanding of the links between food web structure and the efficiency of export (and of destruction) of POM lags behind our understanding of aggregation and sinking. Results presented here suggest that microzooplankton and ballast minerals influence sinking fluxes by ac- celerating the process of aggregation. In addition, added minerals may diminish the enhanced regeneration of ammonium and phosphate driven by microzooplankton, probably by interfering with their grazing on POM.

\subsection{The influence of zooplankton and minerals on nutrient regeneration}

During the experiment, rotifers and added calcite had no effect on the regeneration of DSi (Fig. 8c) from $\mathrm{bSiO}_{2}$ nor on the net production of nitrite (Fig. 8b), but they influenced the regeneration of $\mathrm{NH}_{4}^{+}$and phosphate (Figs. 8d and e) from organic matter.

The rotifers could have had an an influence on silica remineralization by, like bacteria, stripping the $\mathrm{bSiO}_{2}$ of its protective organic coating (Bidle and Azam, 2001), directly exposing the $\mathrm{bSiO}_{2}$ to seawater in which the $\mathrm{bSiO}_{2}$ should dissolve because the DSi concentrations in seawater are severely undersaturated with respect to amorphous silica like $\mathrm{bSiO}_{2}$. It may be that this effect would have taken more than a few days to become detectable, and was thus missed in this experiment.

By the end of the experiment, however, the increase in $\mathrm{NH}_{4}^{+}$concentrations was 4-7 times greater in the $\mathrm{PZ}$ and PZM treatments than in the treatments lacking added rotifers, accounting for $7 \%$ of the loss of PON in the P and PM treatments, $36 \%$ of the loss in the PZ treatment (n.b. in the day 8 tank of which had $30 \%$ fewer zooplankton than the other zooplankton-containing tanks), and $41 \%$ of the loss in the PZM treatment. A net $2.83 \mu \mathrm{mol} \mathrm{L}^{-1}$ of $\mathrm{NH}_{4}^{+}$regeneration in the PZ treatment and $1.38 \mu \mathrm{mol} \mathrm{L}^{-1}$ in the PZM treatment can be ascribed to excretion by rotifers as they fed on diatoms. An $\mathrm{NH}_{4}^{+}$excretion rate $(E)$ per rotifer biomass can be calculated for the 8 day duration of the experiment $(\Delta t)$ using the number of rotifers $(n)$ added at day 0 to the PZ tank (4400 individuals per liter) and to the PZM tank (6200 individuals per liter) sampled on day 8 and the average dry weight per individual Brachionus sp. $\left(\mathrm{DW}_{\mathrm{B}}\right)$ of $0.16 \mu \mathrm{g}$ (Theilacker and McMaster, 1971):

$E=\left(\frac{\left(\left[\mathrm{NH}_{4}\right]_{\mathrm{d} 8}-\left[\mathrm{NH}_{4}\right]_{0}\right)-\mathrm{NRR}}{\left(n \times \mathrm{DW}_{\mathrm{B}}\right)}\right) \div \Delta t$

after subtracting the $0.48 \pm 0.10 \mu \mathrm{mol} \mathrm{L}^{-1}$ of "non-rotifer" regeneration (NRR) of $\mathrm{NH}_{4}^{+}$in the treatments lacking added microzooplankton presumably associated with phytoplankton cell lysis as their physiological condition deteriorated. This yields an $\mathrm{NH}_{4}^{+}$excretion rate of $0.3 \mu \mathrm{g} \mathrm{N} \mathrm{mg}^{-1}$ rotiferh $^{-1}$ in the PZ treatment and of $0.1 \mu \mathrm{g} \mathrm{N} \mathrm{mg}^{-1}$ rotifer $^{-1}$ in the PZM treatment, revealing that the added calcite had an inhibitory effect on feeding by the rotifers. Carrying out this calculation using the quantity of $\mathrm{NH}_{4}^{+}$plus nitrite (assuming that the increase in nitrite during the experiment was fueled by the nitrification of $\mathrm{NH}_{4}^{+}$ and thus nitrite represents an $\mathrm{NH}_{4}^{+}$sink) yields equivalent 


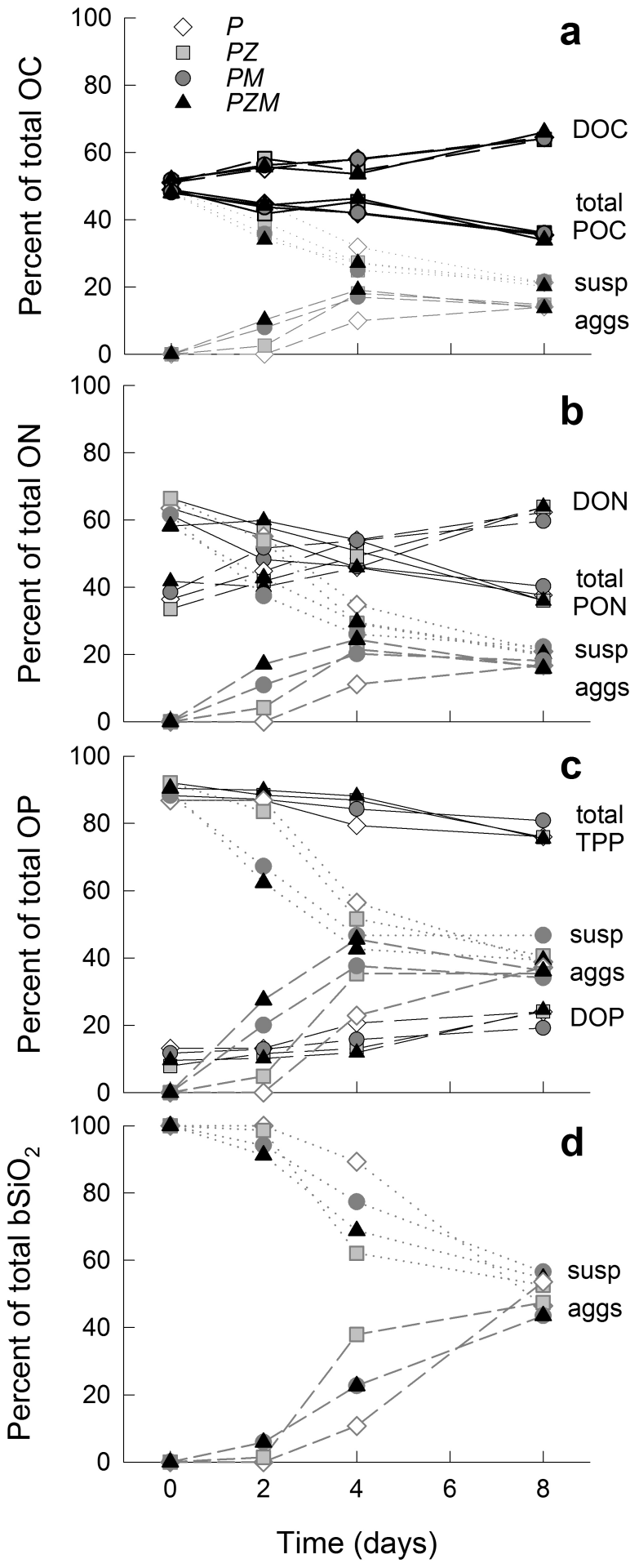

Fig. 5. The percent of the total (a) organic carbon, (b) organic nitrogen, (c) organic phosphorus, and (d) biogenic silica that is in the dissolved organic, total particulate organic (or biogenic), suspended particulate, or aggregate form. Data for suspended and aggregated material are presented to the distribution of particulate matter between these two forms. rates. Such ammonium excretion rates are typical of those found for Brachionus sp. in culture (Hirata and Nagata, 1982; Ejsmont-Karabin, 1983) and for aquatic ecosystems, including those where the zooplankton community is dominated by Brachionus sp. (e.g. Pinto-Coehlo et al., 1997).

Similarly to the increase in ammonium, the increase in phosphate concentration by the end of the experiment is 2 times greater in the two rotifer-containing treatments $(0.88 \pm 0.10 \mu \mathrm{M})$ than in the two treatments lacking rotifers $(0.46 \pm 0.07 \mu \mathrm{M})$. This regeneration accounts for $60 \%$ of the loss of TPP in the P and PM treatments and for $80 \%$ of the loss of the TPP in the PZ and PZM treatments. In addition, the increase in phosphate concentrations was slightly greater in the rotifer-containing treatment that did not contain added calcite (i.e. $0.95 \mu \mathrm{M}$ in PZ) than in the treatment that did (i.e. 0.81 $\mu \mathrm{M}$ in PZM). Adapting Eq. (1) for phosphate yields a phosphate excretion rate of $0.11 \mu \mathrm{g} \mathrm{mg}^{-1}$ rotifer $^{-1}$ in the PZ treatment and $0.07 \mu \mathrm{g} \mathrm{P} \mathrm{mg}{ }^{-1}$ rotifer $\mathrm{h}^{-1}$ in the PZM treatment, lending further support to the notion that the added calcite inhibited rotifer feeding.

These values are a minimum estimate of phosphate excretion because phosphate uptake clearly occurred between days 0 and 2 (Fig. 4e) and may have carried on throughout the experiment. Bacteria are known to take up phosphate and the diatoms may have retained sufficient energy for phosphate uptake, at least for a few days. Judging from the decrease in phosphate in the two treatments lacking zooplankton, the net uptake was $0.15 \mu \mathrm{M}$ between days 0 and 2. Accounting for this in the calculation of phosphate uptake increases the excretion rates to $0.14 \mu \mathrm{g} \mathrm{P} \mathrm{mg}^{-1}$ rotifer $^{-1}$ in the $\mathrm{PZ}$ treatment and $0.09 \mu \mathrm{g} \mathrm{P} \mathrm{mg}^{-1}$ rotifer $^{-1}$ in the PZM treatment.

The added calcite, which was not far off, in terms of concentration and PIC:POC, to coccolithophore blooms (see Sect. 2), had no further visible impact on nutrient regeneration during the experiment beyond their inhibitory effect on the regeneration of ammonium and phosphate by the rotifers, most likely related to physically interfering with grazing. This physical interference could be in the form of a physical obstruction that must be worked around, slowing down the rate at which the rotifers ingest food particles. Alternatively, as the rotifers are relatively non-selective feeders, it could be that, for a given ingestion rate in terms of mass or volume per time, food with a higher mineral content results in a a lower rate of ingestion of POM by rotifers simply because it contains less POM per mass or volume. In either case, the results presented here suggested that in environments with high mineral content relative to POM, be those minerals calcium carbonate, biogenic silica, or lithogenic silicate, rates of organic matter regeneration per biomass of zooplankton could be reduced. 


\subsection{The partitioning of carbon between dissolved and particulate phases}

Aggregates formed more quickly in the treatments that contained rotifers. While it was unlikely that, physically, the rotifers were contributing to aggregation, it may have been that the rotifers or organic compounds associated with their grazing on phytoplankton triggered a greater release of polysaccharides, like transparent exopolymer particles (TEP), by the diatoms in the rotifer-containing treatments. Enhanced rates of TEP production in presence of larger grazers has been observed (Prieto et al., 2001). TEP is important for aggregate formation and on day 2, TEP concentrations were higher in the PZ tanks relative to P tanks (E. Laurenceau, personal communication, 2012).

These observed differences in the initial rates of aggregation between treatments (Figs. 1-5) would have resulted in different patterns of export. More suspended material became more quickly incorporated into aggregates in the mineral-containing treatments (PM and PZM), meaning that for a few days, more of the POM was present in the form of aggregates in the mineral containing treatments than in the two treatments lacking minerals (Fig. 5). Because the aggregates sank an average of $180-380 \mathrm{~m}$ per day (E. Laurenceau, personal communication, 2012) but suspended (non-aggregated) POM did not, the treatments that formed aggregates sooner and faster would have exported more POM earlier than the others. For example, by day 2 , the $\mathrm{P}$ treatment, lacking visible aggregates, would have exported no POC while $6 \%$ of the POC in the PZ treatment and approximately $20 \%$ of the POC in the PM and PZM treatments would have been sinking with an average speed greater than $240 \mathrm{~m} \mathrm{~d}^{-1}$ (E. Laurenceau, personal communication, 2012).

By the end of the experiment the differences between treatments in the extent of aggregation disappeared. Thus, over this time frame (8 days), the presence of minerals and/or rotifers had no impact on the percent of POC that was incorporated into aggregates (Fig. 5). Previous studies with clays, calcium carbonate, and/or silica which have shown that the presence of large quantities of suspended mineral particles speeds up the aggregation of diatoms (Hamm 2002) and alters the size and compactness of the aggregates (Hamm, 2002; Passow and De La Rocha, 2006; De La Rocha et al., 2008; Engel et al., 2009b) did not determine whether or not the minerals increased the total amount of POC incorporated into aggregates.

The rotifers and added calcite minerals had no effect on the partitioning of organic carbon between dissolved and particulate phases (Fig. 5). Although the fraction of the total organic carbon that occurred as DOC increased from $51 \pm 0.5 \%$ to $65 \pm 1 \%$ between day 0 and day 8 for all the treatments due to a decrease in the amount of POC, throughout the experiment the differences between treatments were negligible. Thus neither the rotifers nor the added calcite resulted in enhanced scavenging of DOC into the particulate phase, nor
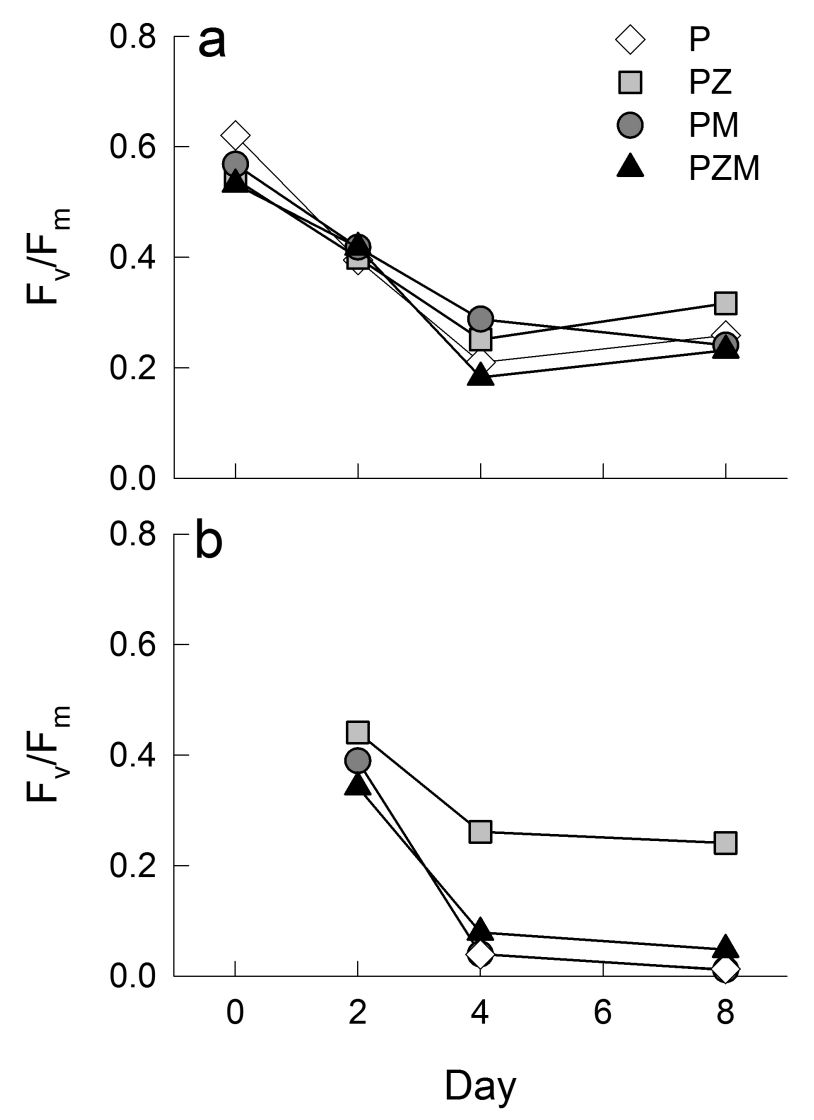

Fig. 6. Photosynthetic efficiency $\left(F_{\mathrm{V}} / F_{\mathrm{m}}\right)$ of phytoplankton in (a) the background water and (b) associated with aggregates.

increased the relative amount of production of DOC from POC.

In terms of these results over 8 days of experiment, it should be noted that the rolling tanks are closed systems. While they allow particles to sink freely, as opposed to pile up on the bottom of the tank, they do not allow sinking particles to be exported from the system. Thus, in this experiment, there was an extended possibility of interaction between suspended and sinking material that would not have necessarily occurred in the ocean, except where sinking particles remain effectively suspended due to turbulence.

\subsection{Was it suspended POM, aggregates, or DOM that remineralized?}

Increases in nutrient concentrations during the experiment due to remineralization appear to have been related to losses of particulate matter rather than DOM because concentrations of DOM tend to either increase over time or remain roughly the same (Figs. 1-3).

Taking the most simple case of regeneration from aggregates versus suspended matter, the per day increase in DSi concentrations increased during the first 4 days of the experiment, from an average of $0.15 \pm 0.06 \mu \mathrm{M} \mathrm{d}^{-1}$ between 


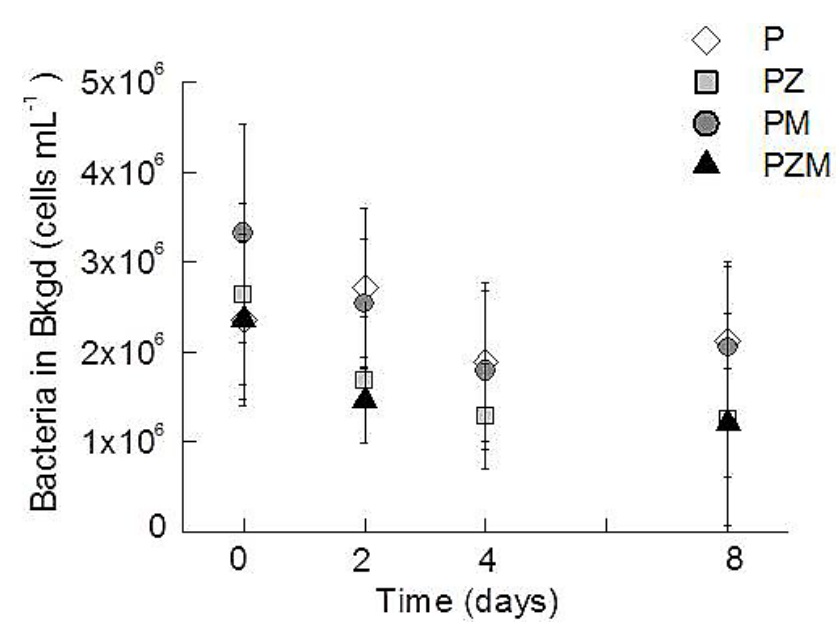

Fig. 7. Abundance of bacteria in the suspended in the background water.

days 0 and 2 to $0.70 \pm 0.19 \mu \mathrm{Md}^{-1}$ between days 2 and 4 . It remained at $0.65 \pm 0.06 \mu \mathrm{M} \mathrm{d}^{-1}$ between between days 4 and 8. This increase in the rate of DSi regeneration is tied likely to the decline in the health of the diatoms indicated by the decline in $F_{\mathrm{v}} / F_{\mathrm{m}}$ (Fig. 6). In fact, there is a strong negative correlation between the $F_{\mathrm{v}} / F_{\mathrm{m}}$ of suspended plankton and the increase in DSi concentration, with DSi increasing by $3.0 \mu \mathrm{M} \mathrm{d}^{-1}$ for each unit of decrease in $F_{\mathrm{v}} / F_{\mathrm{m}}\left(r^{2}=0.82\right.$; $n=12 ; p<0.01)$. Given that there were large differences in the speed of aggregate formation between treatments, the overall similarity in DSi regeneration (Fig. 8c) suggests that the dissolution of biogenic silica occurred equitably between suspended diatoms and diatoms in aggregates. Beyond that, it is difficult to say to what extent remineralization was driven by the decomposition of suspended matter versus the decomposition of material in aggregates. If any loss of matter from aggregates occurred, it was masked by the process of aggregation during the experiment.

\subsection{Probable feeding behaviour of the rotifers}

The rotifers were capable of feeding on the aggregates that formed during the experiment. Rotifers are selective feeders able to home in on concentrated patches of food (Ignoffo et al., 2005). Marine species such as Brachionus sp. can feed on diatoms and are known to graze on coccolith-containing coccolithophorids (Harris, 1994), meaning that the POM in this experiment should have been available to them. Rotifers are also known to graze on aggregates (Zimmermann-Timm et al., 1998) and were observed associated with the aggregates during the experiment (Fig. 10). The rotifers were of course too small to feed on entire aggregates, but the individual diatoms present within the aggregates were well within the range of the 5 to $12 \mu \mathrm{m}$ equivalent spherical diameter (ESD) preferred by Brachionus sp. (Rothhaupt, 1990). Although Brachionus sp. may have also fed on suspended
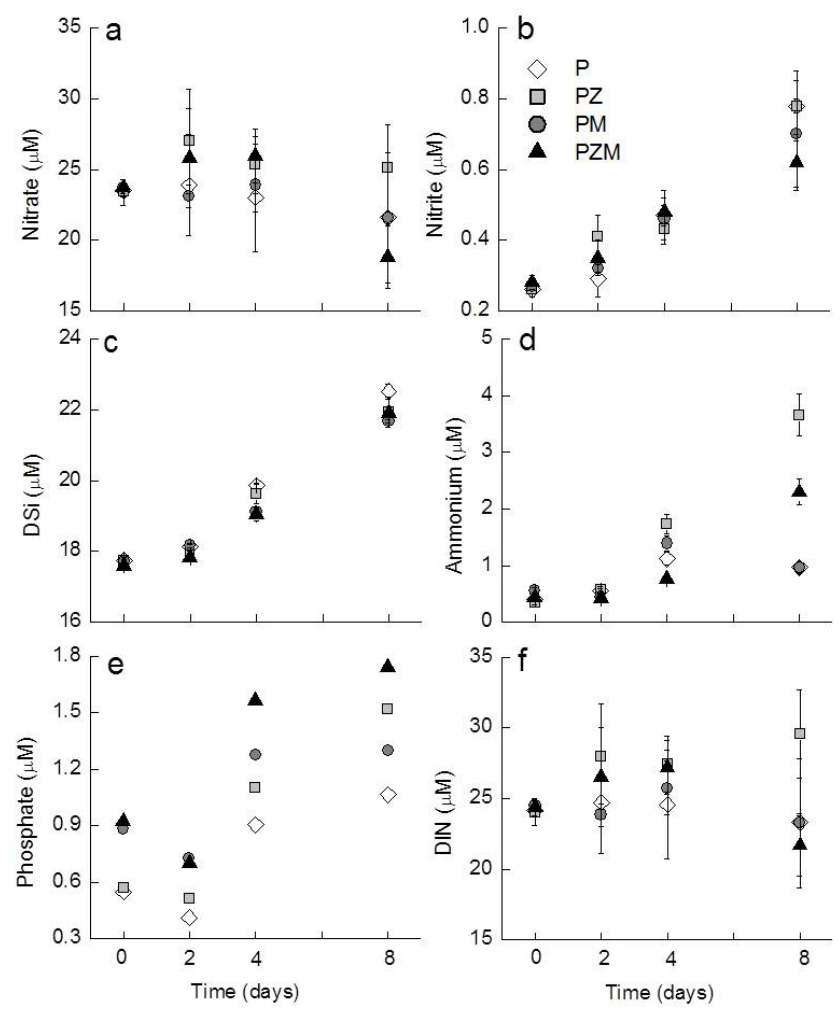

Fig. 8. Concentrations of (a) nitrate, (b) nitrite, (c) DSi, (d) ammonium, (e) phosphate, and (f) DIN (nitrate + nitrite + ammonium) in the tanks.
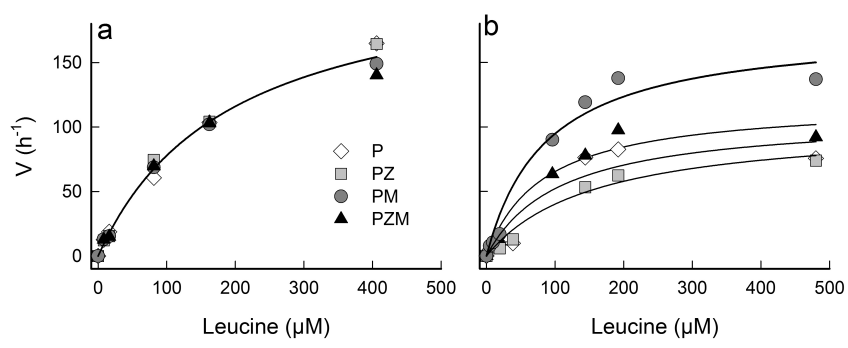

Fig. 9. Aminopeptidase activity in the background water of the tanks on days 0 (a) and 8 (b) as determined from the hydrolysis of leucine. The values of $V_{\max }$ and $K_{\mathrm{S}}$ for the curve shown in (a) are $227 \pm 10 \mathrm{~h}^{-1}$ and $192 \pm 18 \mu \mathrm{M}\left(r^{2}=0.99\right)$. In (b), the highest curve (the one for PM) has a $V_{\max }$ of $177 \pm 19 \mathrm{~h}^{-1}$ and a $K_{\mathrm{S}}$ of $87 \pm 28 \mu \mathrm{M}\left(r^{2}=0.97\right)$, while the lowest curve (the one for PZ) has a $V_{\max }$ of $103 \pm 14 \mathrm{~h}^{-1}$ and a $K_{\mathrm{S}}$ of $157 \pm 50 \mu \mathrm{M}\left(r^{2}=0.98\right)$.

POM, observations of them grazing on the periphery of the aggregates during the experiment (Fig. 10) confirms that they fed at least partly on aggregates.

\section{Conclusions}

This work has demonstrated, in a simple way, that food web structure influenced the remineralization of nutrients from a 


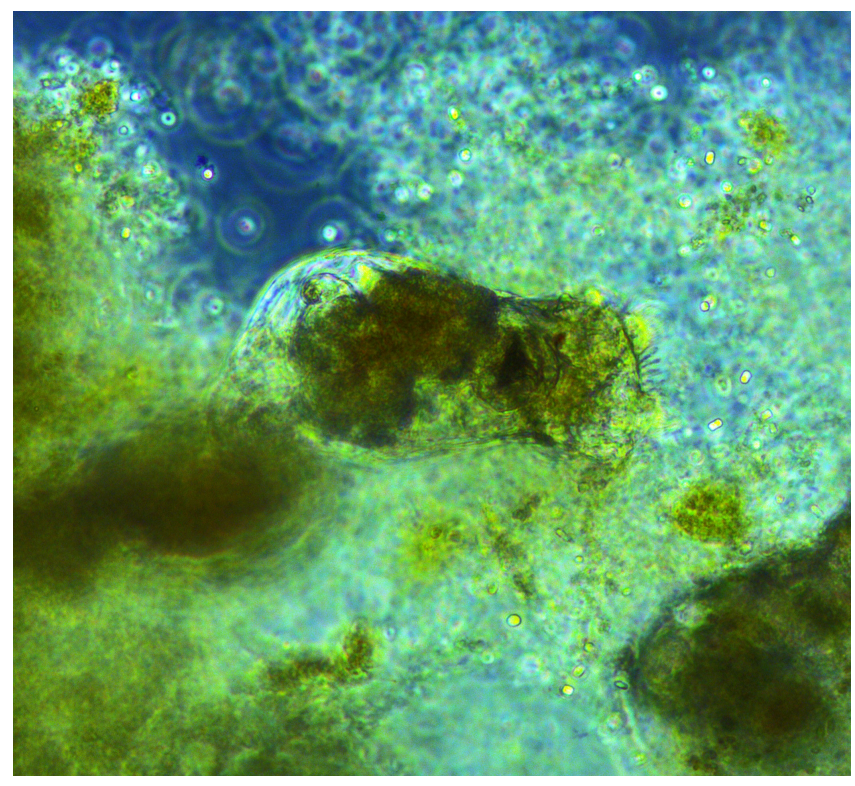

Fig. 10. Image of rotifer associated with (and actively feeding on) an aggregate during the experiment.

population of diatoms, at least $40 \%$ of which were associated with aggregates for more than half the duration of the experiment. In this case, the presence of rotifers resulted in enhanced remineralization of $\mathrm{NH}_{4}^{+}$and phosphate during the experiment. The dissolution of $\mathrm{bSiO}_{2}$ into DSi was not affected by the presence of either the rotifers or the presence of calcite. More interestingly, the presence of added calcite minerals diminished the enhanced rates of $\mathrm{NH}_{4}^{+}$regeneration and phosphate regeneration related to grazing by microzooplankton (rotifers) by $67 \%$ and $36 \%$, although the estimate for phosphate regeneration is an underestimate due to phosphate uptake by phytoplankton and/or bacteria during the experiment. They key point here is that ballast minerals such as calcite, by decreasing the speed or efficiency of feeding on particulate organic matter by zooplankton, can slow down the rate of remineralization of sinking organic matter, increasing the export efficiency of the biological pump. Lastly, the presence of the microzooplankton and of the added calcite increased the initial rate of aggregation, although they did not result in an overall greater amount of POM incorporated into aggregates in the different treatments by the end of the experiment. Because of the high sinking speeds of the aggregates, this faster initial formation of aggregates would have resulted in earlier export of organic matter from these systems in the treatments containing zooplankton and minerals.

Acknowledgements. We thank H. Stibor, Oceanopolis Brest, P. Pondaven, , A. C. Baudoux, R. Corvaisier, A. Masson, C. Liourzou (IUEM), E. Achterberg, C. Dumousseau, Z. Chowdhury, (NOC), C. Labry (IFREMER) for technical support, discussions, and/or advice and the anonymous reviewers for insightful com- ments. This work was supported by the CalMarO FP7 Marie Curie Initial Training Network (www.calmaro.eu, grant agreement no. 215157), Region Bretagne, and EURO-BASIN (No. 264933), an Integrating Project of the European Community 7th Framework Programme.

\section{Edited by: G. Herndl}

\section{References}

Aminot, A. and Kerouel, R.: An automated photo-oxidation method for the determination of dissolved organic phosphorus in marine and fresh water, Mar. Chem., 76, 113-126, 2001.

Aminot, A. and Kerouel, R.: Dosage automatique des nutriments dans les eaux marines, in, Editions de l'IFREMER, ISBN 978-27592-0023-8, 188 pp., 2007.

Armstrong, R. A., Lee, C., Hedges, J. I., Honjo, S., and Wakeham, S. G.: A new, mechanistic model for organic carbon fluxes in the ocean based on the quantitative association of POC with ballast minerals, Deep-Sea Res. II, 49, 219-236, 2002.

Bidle, K. D. and Azam, F.: Bacterial control of silicaon regeneration from diatom dtritus: significance of bacterial ectohydrolases and species identity, Limnol. Oceanogr., 46, 1606-1623, 2001.

Broecker, W. S. and Peng, T.-H.: Tracers in the Sea, Eldigio, New York, 690 pp., 1982.

Castilho, M. S. M. and Arcifa, M. S.: Production of the rotifer Brachionus plicatilis (Ploimida: Brachionidae) in a Brazilian coastal lagoon, Rev. Biol. Trop., 48, 859-865, 2000.

De La Rocha, C. L. and Passow, U.: Factors influencing the sinking of POC and the efficiency of the biological carbon pump, DeepSea Res. II, 54, 639-658, 2007.

De La Rocha, C. L., Nowald, N., and Passow, U.: Interactions between diatom aggregates, minerals, particulate organic carbon, and dissolved organic matter: Further implications for the ballast hypothesis, Global Biogeochem. Cy., 22, GB4005, doi:10.1029/2007GB003156, 2008.

Deuser, W. G., Ross, E. H., and Anderson, R. F.: Seasonality in the supply of sediment to the deep Sargasso Sea and implications for the rapid transfer of matter to the deep ocean, Deep-Sea Res., 28, 495-505, 1981.

Ejsmont-Karabin, J.: Ecological characteristics of lakes in Northeastern Poland versus their trophic gradient. VIII. Role of nutrient regeneration by planktonic rotifers and crustaceans in 42 lakes, Ekol. Pol., 31, 411-427, 1983.

Engel, A., Abramson, L., Szlosek, J., Liu, Z., Stewart, G., Hirschberg, D., and Lee, C.: Investigating the effect of ballasting by $\mathrm{CaCO}_{3}$ in Emiliania huxleyi: II. Decomposition of particulate organic matter, Deep-Sea Res. II, 56, 1408-1419, 2009 a.

Engel, A., Szlosek, J., Abramson, L., Liu, Z., and Lee, C.: Investigating the effect of ballasting by $\mathrm{CaCO}_{3}$ in Emiliania huxleyi: I. Formation, settling velocities and physical properties of aggregates, Deep-Sea Res. II, 56, 1396-1407, 2009b.

Falkowski, P. G., Barber, R. T., and Smetacek, V.: Biogeochemical controls and feedbacks on ocean primary production, Science, 281, 200-206, 1998.

Fischer, G. and Karakaş, G.: Sinking rates and ballast composition of particles in the Atlantic Ocean: implications for the organic carbon fluxes to the deep ocean, Biogeosciences, 6, 85102, doi:10.5194/bg-6-85-2009, 2009. 
François, R., Honjo, S., Krishfield, R., and Manganini, S.: Factors controlling the flux of organic carbon to the bathypelagic zone of the ocean, Glob. Biogeochem. Cy., 16, 1087, doi:10.1029/2001GB001722, 2002.

Hamm, C. E.: Interactive aggregation and sedimentation of diatoms and clay-sized 700 lithogenic material, Limnol. Oceanogr. 47, 1790-1795, 2002.

Harlay, J., Chou, L., De Bodt, C., Van Oostende, N., Piontek, J., Suykens, K., Engel, A., Sabbe, K., Groom, S., Delille, B., and Borges, A. V.: Biogeochemistry and carbon mass balance of a coccolithophore bloom in the nothern bay Bay of Biscay (June 2006), Deep-Sea Res. I, 58, 111-127, 2011.

Harris, R. P.: Zooplankton grazing on the coccolithore Emiliania huxleyi and its role in organic carbon flux, Mar. Biol., 119, 431439, 1994.

Henson, S., Sanders, R., Madsen, E., Morris, P. J., Le Moigne, F., Quartly, G. D.: A reduced estimate of the strength of the ocean's biological carbon pump, Geophys. Res. Lett., 38, L046006, doi:10.1029/2011GL046735, 2011.

Hirata, H. and Nagata, W. D.: Excretion rates and excreted components of the rotifer Brachionus plicatilis O.F. MÜLLER in culture, Mem. Fac. Fish. Kagoshima Univ., 31, 161-174, 1982.

Hoppe, H.-G., Kim, S. J., and Gocke, K.: Microbial decomposition in aquatic environments: Combined process of extracellular enzyme activity and substrate uptake, Appl. Environ. Microbiol., 54, 784-790, 1988.

Ignoffo, T. R., Bollens, S. M., and Bochdansky, A. B.: The effects of thin layers on the vertical distribution of the rotifer, Brachionus plicatilis, J. Exp. Mar. Biol. Ecol., 316, 167-181, 2005.

Ingalls, A. E., Liu, Z., and Lee, C.: Seasonal trends in the pigment and amino acid compositions of sinking particles in biogenic $\mathrm{CaCO}_{3}$ and $\mathrm{SiO}_{2}$ dominated regions of the Pacific sector of the Southern Ocean along $170^{\circ} \mathrm{W}$, Deep-Sea Res. I, 53, 836-859, 2006.

Iversen, M. H. and Ploug, H.: Ballast minerals and the sinking carbon flux in the ocean: carbon-specific respiration rates and sinking velocity of marine snow aggregates, Biogeosciences, 7 , 2613-2624, doi:10.5194/bg-7-2613-2010, 2010.

Iversen, M. H., Nowald, N., Ploug, H., Jackson, G. A., and Fischer, G.: High resolution profiles of vertical particulate matter export off Cape Blanc, Mauritania: Degradation processes and ballasting effects, Deep-Sea Res. I, 57, 711-784, 2010.

Kirk, K. L.: Suspended clay reduces Daphnia feeding rate. Freshwater Biol. 25, 357-365, 1991.

Klaas, C. and Archer, D. E.: Association of sinking organic matter with various types of mineral ballast in the deep sea: Implications for the rain ratio, Glob. Biogeochem. Cy., 16, 1116, doi:10.1029/2001GB001765, 2002.

Koroleff, F.: Direct determination of ammonia in natural water as indophenol blue, in: Information on Techniques and Methods for Seawater Analysis, Int. Con. Explor. Sea, Interlab Report Number 3, 19-22, 1969.

Le Quéré, C., Takahashi, T.,. Buitenhuis, E. T., Rödenbeck, C., and Sutherland, S. C.: Impact of climate change and variability on the global ocean sink of $\mathrm{CO}_{2}$, Glob. Biogeochem. Cy., 24, GB4007, doi:10.1029/2009GB003599, 2010.

Lee, C., Peterson, M. L. Wakeham, S. G., Armstrong, R. A., Cochran, J. K., Miquel, J. C., Fowler, S. W., Hirschberg, D., Beck, A., and Xue, J.: Particulate organic matter and ballast fluxes measured using time-series and settling velocity sediment traps in the northwestern Mediterranean Sea, Deep-Sea Res. II, 56 1420-1436, 2009.

Lorrain, A., Savoye, N., Chauvaud, L., Paulet, Y.-M., and Naulet, N.: Decarbonation and preservation method for the analysis of organic $\mathrm{C}$ and $\mathrm{N}$ contents and stable isotope ratios of lowcarbonated suspended particulate material, Anal. Chim. Acta, 491, 125-133, 2003.

Pan, X., Sanders, R., Tappin, A. D., Worsfold, P. J., Achterberg, E. P.: Simultaneous determination of dissolved organic carbon and total dissolved nitrogen on a coupled high-temperature combustion total organic carbon-nitrogen chemiluminescence detection (HTC TOC-NCD) system, J. Autom. Methods Manag. Chem., 2005, 240-246, 2005.

Parekh, P., Dutkiewicz, S., Follows, M. J., and Ito, T.: Atmospheric carbon dioxide in a less dusty world, Geophys. Res. Lett., 33, L03610, doi:10.1029/2005GL025098, 2006.

Parkhill, J. P., Maillet, G., Cullen, J. J.: Fluorescence-based maximal quantum yield for PSII as a diagnostic of nutrient stress, J. Phycol., 37, 517-529, 2001.

Passow, U. and De La Rocha C. L.: Accumulation of mineral ballast on organic aggregates, Glob. Biogeochem. Cy., 20, GB1013, doi:10.1029/2005GB002579, 2006.

Passow, U., Engel, A., and Ploug, H.: The role of aggregation for the dissolution of diatom frustules, FEMS Microbiol. Ecol., 46, 247-255, 2003.

Pinto-Coehlo, R. M., Texeira de Moura, R., and Moreira, A.: Zooplankton and bacteria contribution to phosphorus and nitrogen internal cycling in a tropical and eutrophic reservoir: Pamulha Lake, Brazil, Int. Revue Ges. Hydrobiol., 82, 185-200, 1997.

Prieto, L., Sommer, F., Stibor, H., and Koeve, W.: Effects of planktonic copepods on transparent exopolymeric particles (TEP) abundance and size spectra, J. Plankton Res., 23, 515-525, 2001.

Ploug, H., Iversen, M. H., Fischer, G.: Ballast, sinking velocity, and apparent diffusivity within marine snow and zooplankton fecal pellets: Implications for substrate turnover by attached bacteria, Limnol. Oceanogr., 53, 1878-1886, 2008.

Poulton, A. J., Sanders, R., Holligan, P. M., Stinchcombe, M. C., Adey, T. R., Brown, L., and Chamberlain, K.: Phytoplankton mineralization in the tropical and subtropical Atlantic Ocean, Glob. Biogeochem. Cy., 20, GB4002, doi:10.1029/2006gb002712, 2006.

Ragueneau, O., Savoye, N., Del Amo, Y., Cotten, J., Tardiveau, B., and Leynaert, A.: A new method for the measurement of biogenic silica in suspended matter of coastal waters: using Si:Al ratios to correct for the mineral interference, Cont. Shelf Res., 25, 697$710,2005$.

Riley, J., Sanders, R., Marsay, C., Le Moigne, F. A. C., Achterberg, E. P., and Poulton, A. J.: The relative contribution of fast and slow sinking particles to ocean carbon export, Glob. Biogeochem. Cy., 26, GB1026, doi:10.1029/2011GB004085, 2012.

Rothhaupt, K. O.: Differences in particle-size dependent feeding efficiencies of closely related rotifer species, Limnol. Oceanogr., 35, 16-23, 1990.

Sanders, R., Morris, P. J., Poulton, A. J., Stinchcombe, M. C., Charalampopoulou, A., Lucas, M. I., and Thomalla S. J.: Does a ballast effect occur in the surface ocean?, Geophys. Res. Lett., 37, L08602, doi:10.1029/2010GL042574, 2010. 
Shanks, A. L. and Trent, J. D.: Marine snow - Sinking rates and potential role in vertical flux, Deep-Sea Res., 27, 137-143, 1980.

Theilacker, G. H. and McMaster, M. F.: Mass culture of the rotifer Brachionus plicatilis and it sevaluation as a food larval anchovies, Mar. Biol., 10, 183-188, 1971.

Thomalla, S. J., Poulton, A. J., Sanders, R., Turnewitsch, R., Holligan, P. M., and Lucas, M. I.: Variable export fluxes and efficiencies for calcite, opal, and organic carbon in the Atlantic Ocean: A ballast effect in action?, Glob. Biogeochem. Cy., 22, GB1010, doi:10.1029/2007GB002982, 2008.

Vanderploeg, H. A., Eadie, B. J., Liebig, J. R., Tarapchak, S. J., and Glover, R. M.: Contribution of calcite to the particle-size spectrum of Lake Michigan seston and its interactions with the plankton, Can. J. Fish. Aquat. Sci., 44, 1898-1914, 1987.
Von Brand, T., Rakestraw, N. W., and Renn, C. E.: Decomposition and regeneration of nitrogenous organic matter in sea water, Biol. Bull., 273-282, 1942.

Yoon, W. B. and Rosson, R. A.: Improved method of enumeration of attached bacteria for study of fluctuation in the abundance of attached and free-living bacteria in response to diel variation in seawater turbidity, Appl. Environ. Microbiol., 56, 595-600, 1990.

Zimmermann-Timm, H., Holst, H., and Müller, S.: Seasonal dynamics of aggregates and their typical biocoenosis in the Elbe Estuary, Estuaries, 21, 613-621, 1998. 